\title{
FIRST DIRECT AMS DATES ON EARLY MAIZE FROM TEHUACÁN, MEXICO
}

\author{
AUSTIN LONG*, B F BENZ**, D J DONAHUE ${ }^{+}$, A J T JULL* \\ and L J TOOLIN*
}

\begin{abstract}
The Tehuacán region in Central Mexico is thought to be the locale of origin of Zea mays, or maize, a cultivated plant pivotal in the development of agriculture in the Americas (MacNeish, 1981, 1985). The age of the earliest maize, and its rate of dispersal are thus important components of cultural development in the New World. We have secured permission from the Federal Government of Mexico to date critical specimens from Tehuacán, which represent what are probably some of the earliest known stages of maize evolution. Twelve Zea mays samples have been dated, six from Cueva San Marcos and six from Cueva Coxcatlán. These were selected as having the best stratigraphic control and correlation with previously dated charcoal samples, and to represent the most ancient maize. Corn from Cueva San Marcos is oldest: four of the six specimens from this cave were within statistics of $4700 \mathrm{BP}$ (uncalibrated). The oldest known domesticated corn is thus no older than $3600 \mathrm{cal} \mathrm{BC}$ (dendro-calibrated in calendric years).
\end{abstract}

\section{INTRODUCTION}

The domestication of corn (maize) was one of the significant events in cultural development. Strong evidence exists (see, eg, Mangelsdorf, 1974; Iltis, 1983) that this event occurred in one geographic area and people carried the plants and technology to other parts of the world. Archaeological evidence (Mangelsdorf, MacNeish \& Galinat, 1964, 1967) compellingly suggets that the earliest maize grew in the Tehuacán Valley of central Mexico. Until now, the botanical specimens representing the early evolution of corn, owing to their small size and great value to ethnobotany, have been dated only by association with radiocarbon-dated charcoal and other non-maize material in archaeological sites. The purpose of this investigation is to determine the ages of representative earliest corn specimens directly by accelerator mass spectrometry (AMS).

\section{SELECTION OF SITES AND SAMPLES}

Of several cave sites in the Tehuacán Valley that have undergone extensive investigations (Mangelsdorf, MacNeish \& Galinat, 1964, 1967), three appear to record the domestication of corn (see also Benz \& Iltis, ms; Benz, 1987, 1988). These are Cueva San Marcos, Cueva Coxcatlán and Cueva Purron. The Coxcatlán cultural phase, recognized in these caves, contained the earliest corn specimens. Radiocarbon dates on wood and charcoal analyzed in the 1960 s by the original investigators indicate that this phase began ca $7000 \mathrm{BP}$ (uncal), and ended ca $5350 \mathrm{BP}$ (uncal). The results reported here are on maize specimens from San Marcos and Coxcatlán cave deposits assigned by MacNeish and collaborators to the Coxcatlán phase, and a single specimen assigned to the Abejas phase.

* Department of Geosciences, University of Arizona, Tucson, Arizona 85721

**Laboratorio Natural las Joyas de la Sierra de Manantlan, Universidad de Guadalajara, Guadalajara, Jalisco CP 44100, Mexico

+ Department of Physics, University of Arizona 
The corn specimens of interest have been in the custody of the Instituto Nacional de Antropología e Historia (INAH), in Mexico City since their initial collection and analysis by RS MacNeish, analysis by PC Mangelsdorf and WC Galinat, and return in the 1970s. Specimens were selected to represent the oldest maize in the collection. The actual samples collected for dating are cob fragments. They were still in the original specimen containers used by Galinat. From these, we asked MacNeish to select 12 that he considered to have the best proveniences and relationships to well-dated levels. We here report the results of these samples.

\section{SAMPLE PRETREATMENT AND CARBON ISOTOPE ANALYSIS PROCEDURES}

Each specimen was examined macro- and microscopically for evidence of cotton, in which they had been packaged during storage. All remnants of cotton were removed. No evidence of microbiological activity was apparent during the examination. Some specimens in the collection had been preserved in glycerin. None of these was sampled for ${ }^{14} \mathrm{C}$ analysis. Since glycerin is water-soluble, had it been on one which we analyzed, the chemical pretreatment would have removed it all.

Specimens were treated with distilled $0.6 \mathrm{~N}$ hydrochloric acid, then washed with distilled water until $\mathrm{pH}$ was neutral. No effervescence occurred in acid, but most solutions showed slight yellow coloration. Specimens experienced minor weight loss during chemical pretreatment. This pretreatment should have removed carbonate dust, traces of glycerin and fingerprints.

One to two milligram samples of the specimens were combusted to carbon dioxide. The carbon dioxide, after stable carbon analysis on a VG 602 mass spectrometer, was graphitized by the standard procedure employed in the Arizona AMS laboratory (Slota et al, 1987). The graphite was then analyzed for ${ }^{14} \mathrm{C}$ on the accelerator (Donahue, Jull \& Zabel, 1984).

\section{RESULTS}

Table 1 lists the 12 samples, their field collection numbers and stratigraphic positions, as well as the stable isotope results (numbers in parenthesis are values assumed for computational purposes) and the ${ }^{14} \mathrm{C}$ results. Both the uncalibrated but stable-isotope-normalized dates and the calibrated date ranges (67\% confidence ranges) are listed. All dates are calibrated using curves in Stuiver and Pearson (1986) and Pearson and Stuiver (1986).

Figure 1 is a comparison of the present results with the ${ }^{14} \mathrm{C}$ dates obtained in the original Tehuacán chronometric analysis of Johnson and MacNeish (1972). The two sets of data, the wood and charcoal dates representing the stratigraphic horizons from which the corn was collected, and the AMS dates on the corn itself are clearly different, with no statistical overlap. The oldest corn AMS dates are 1500 years younger than the average age of the Coxcatlán phase based on previous work. This clear discrepancy deserves further investigation. 
Table 1

AMS - dated maize specimens from Tehuacan Valley, Mexico

\begin{tabular}{|c|c|c|c|c|c|c|}
\hline AA-No. & A-No. & Target & Sample I D & ${ }^{13} \mathrm{CPDB}^{*}$ & ${ }^{14} \mathrm{C}$ date & Calibrated range \\
\hline \multicolumn{7}{|c|}{ Cueva San Marcos } \\
\hline 3304 & 5009 & V3892 & $\begin{array}{l}\text { W2, 14-3i. } \\
\text { Zone D }\end{array}$ & -10.8 & $4680 \pm 50$ & $3500-3380$ вС \\
\hline 3305 & 5010 & $\mathrm{X} 135$ & $\begin{array}{l}\text { N1E1, 3-5i. } \\
\text { Zone E }\end{array}$ & -8.6 & $4700 \pm 60$ & $3500-3380$ вС \\
\hline 3306 & 5011 & V3895 & $\begin{array}{l}\text { N1E1, 3-5i } \\
\text { Zone E (A) }\end{array}$ & $(-10.0)$ & $4150 \pm 50$ & $2880-2660$ вС \\
\hline 3310 & 5029 & V3897 & $\begin{array}{l}\text { N1, 2-4i } \\
\text { Zone E }\end{array}$ & $(-10.0)$ & $4600 \pm 60$ & $3380-3360$ вС \\
\hline 3311 & 5030 & V3889 & $\begin{array}{l}\text { N1E1, 3-6i } \\
\text { Zone F }\end{array}$ & -10.1 & $4700 \pm 110$ & $3640-3360$ вс \\
\hline 3315 & 5036 & V3899 & $\begin{array}{l}\text { S1W3, 18-5i } \\
\text { Zone D }\end{array}$ & $(-10.0)$ & $1560 \pm 45$ & AD $440-620$ \\
\hline \multicolumn{7}{|c|}{ Cueva Coxcatlan } \\
\hline 3307 & 5014 & V3896 & $\begin{array}{l}\text { W2. 24-11i, \#1 } \\
\text { Zone XIII }\end{array}$ & $(-10.0)$ & $1900 \pm 60$ & AD 20-200 \\
\hline 3308 & 5017 & V3890 & $\begin{array}{l}\text { S1W6, 7-6i, } \\
\text { Zone XIII }\end{array}$ & -9.5 & $4090 \pm 50$ & $2870-2580$ вС \\
\hline 3309 & 5018 & V3893 & $\begin{array}{l}\text { W1, 36-8i, \#1, } \\
\text { XI }\end{array}$ & -9.8 & $1860 \pm 45$ & AD $80-220$ \\
\hline 3312 & 5031 & V3891 & $\begin{array}{l}\text { W3 bottom, XI } \\
13-7 \mathrm{i}\end{array}$ & -8.8 & $4040 \pm 100$ & $2580-2500$ вс \\
\hline 3313 & 5033 & V3898 & $\begin{array}{l}\text { S2, 74-12i } \\
\text { XIII }\end{array}$ & $(-10.0)$ & $3740 \pm 60$ & $2280-2040$ вС \\
\hline 3314 & 5034 & V3894 & $\begin{array}{l}\text { N1W4 149-5i } \\
\text { Zone XII }\end{array}$ & -11.7 & $450 \pm 40$ & AD $1400-1460$ \\
\hline
\end{tabular}

${ }^{*}$ Assumed ${ }^{13} \mathrm{C}$ values shown in parenthesis

\section{DISCUSSION}

The data shown here from Johnson and MacNeish (1972) are only a small portion of their chronometric analysis. Their dates shown on figure 1 are consistent with $>200{ }^{14} \mathrm{C}$ dates used in their study, 84 from the Tehuacán Valley, and the age span they derived for the Coxcatlán phase is consistent with the dates from older and younger phases. It is not the purpose of this study to question the credibility of the previous dates or their interpretation. We will, however, examine possible sources of error in the new AMS dates, and pose some possible explanations for the discrepancies.

As the AMS dates are significantly younger than the previous ones, the question of contamination must be addressed. In order to shift the apparent age of a sample actually 6000 years old, 1300 years toward the present to $4700 \mathrm{BP}, 15 \%$ of the carbon in the sample must be modern contamination, eg, cotton fibers. This amount of cotton in the corn sample would be hard 


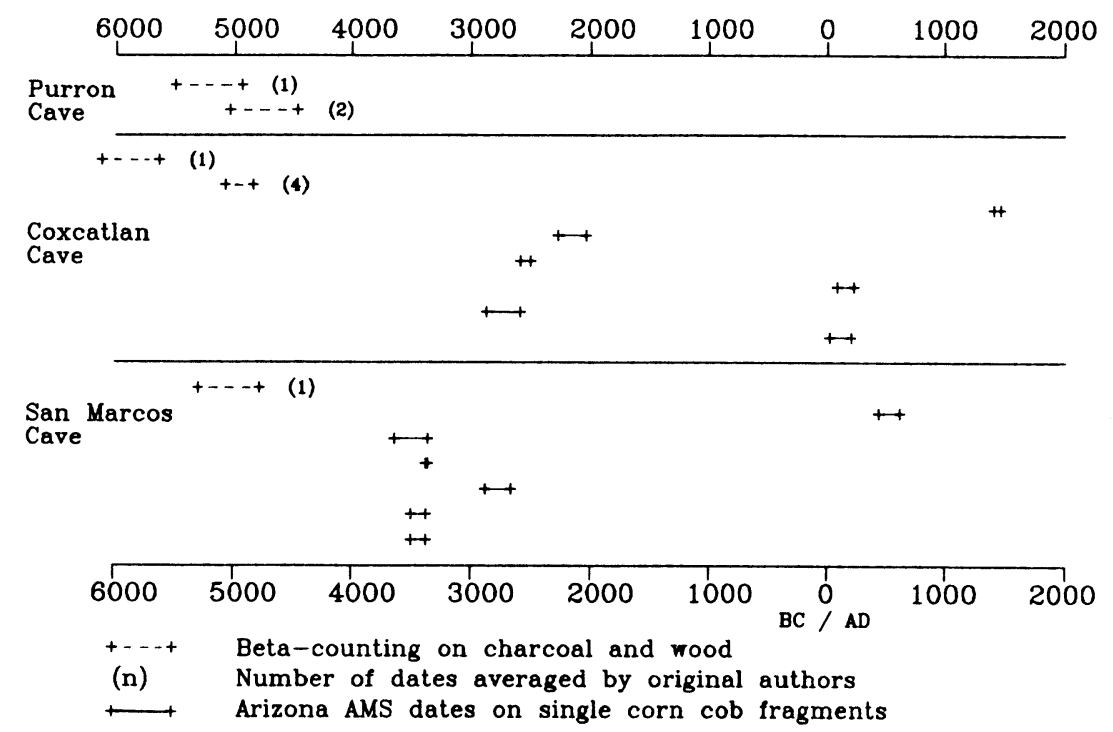

Fig 1. Coxcatlan phase dendro-calibrated dates ( $1 \sigma$ range)

to miss in the microscope. Fifteen percent cotton, or any other $\mathrm{C}_{3}$-type plant or plant-derived preservative, including petrochemicals would shift the $\delta^{13} \mathrm{C}$ by almost $3 \%$ toward more negative values than those shown in Table 1 . On the contrary, these oldest corn samples are the least negative of any in the literature. Moreover, petrochemical contamination would make the samples appear older than true age. W C Galinat (pers commun) states that only glycerin could have been added, and it would have been apparent from their wet appearance. Glycerin, being water-soluble, would have been removed during laboratory pretreatment (see above). The specimens were still in the vials Galinat placed them in when we sampled them. Curators at the INAH assured us they did not chemically treat them, and our observations verify this. Another fact inconsistent with contamination is that the 4 oldest of the 6 samples from San Marcos cave are in statistical agreement. Contamination is not usually that deceptive.

The question arises whether corn itself yields valid ${ }^{14} \mathrm{C}$ dates. As corn has a relatively short growing season, and is an annual plant, could its brief photosynthetic sampling of atmospheric ${ }^{14} \mathrm{C}$ produce anomalous ages not found in plants integrating longer sample times of atmospheric carbon dioxide? Single-year tree-ring samples show variations almost entirely obscured by high-precision ${ }^{14} \mathrm{C}$ counting statistics (Damon, Long \& Wallick, 1973a, b). Moreover, Creel and Long (1986) treated the question of the reliability of corn dates in some detail (in which corn was dated by high-precision $\beta$-counting), and concluded that corn is an ideal sample type for ${ }^{14} \mathrm{C}$ dating. Finally, recent data from Bat Cave, New Mexico show that in many cases, charcoal and AMS-dated corn collected from the same stratum yielded the same date (Wills, 1985; Long et al, 1986; ms in preparation), while in other 
instances the corn was younger. At Bat Cave, corn younger than its surrounding charcoal was explained by mixing within the stratigraphic context rather than by some problem unique to corn. We find no compelling evidence for errors in ${ }^{14} \mathrm{C}$ dates on corn itself, dated either traditionally or by AMS.

We conclude from the above that the dates reported here are the true ${ }^{14} \mathrm{C}$ ages of the specimens. We feel the discrepancy must lie elsewhere. Possibilities include stratigraphic disturbances undetectable in the field, and mislabeling of sample containers during curation or laboratory processing. We are not able to evaluate the field situation, but morphological criteria are available to us. The relative ages of the oldest specimens in San Marcos and Coxcatlán Caves are consistent with morphological characteristics: those from San Marcos appear more primitive. In addition, the AD-period dates, though clearly stratigraphically anomalous, may represent intrusions of later relics of the same primitive corn (Benz, 1988; ms in prepartion).

If the dates revealed in this study are correct, and if we have, in fact, dated the earliest corn, then its initial appearance occurred 1500 to 2500 years later than currently believed. Corn appeared in North America by 1000 $\mathrm{BC}$, allowing a reasonable, though rapid, migration time from Tehuacán.

\section{CONCLUSIONS}

The first ${ }^{14} \mathrm{C}$ dates on the earliest appearance of Zea mays in the Tehuacán Valley of Mexico do not confirm the stratigraphically associated ${ }^{14} \mathrm{C}$ dates on charcoal and wood. The oldest corn found in this study is ca $3500 \mathrm{cal} \mathrm{BC}$, which is up to 2500 years younger than presently believed. Sample contamination is an unlikely explanation for discrepancies between the present results and those from previous studies. If the dates reported here record the earliest corn domestication, models for agriculture technology migration rate may require revision.

\section{FURTHER WORK}

The tentative conclusions of this study are important enough to warrant confirmation. Therefore, we plan to continue AMS dating of cultural material, especially remains of other edible plants in the assemblages from the collections in Mexico.

\section{ACKNOWLEDGMENTS}

This work was supported by funds from NSF 8505083, NSF EAR 8309448, and NSF DEB 8022772 and travel support from the University of Wisconsin Davis Fund. We also gratefully acknowledge financial assistance from Pioneer Hi-Bred International, Inc and $\mathrm{H}$ Iltis. We thank RM Kalin for technical assistance. Thanks are also due J Garcia Barcena, L Mirambell, F Sanchez and C Alvarez del Castillo of INAH for permission to conduct the analyses and for assistance while working with the collection. 


\section{REFERENCES}

Benz, BF, Racial systematics and the evolution of Mexican maize, in Manzanilla, L, ed, Studies in the Neolithic and urban revolutions: The V Gordon Childe Colloquium, Mexico, 1986, BAR Internatl ser, p 121-136.

(ms) 1988, The "wild maize" from Tehuacan revisited: Paper presented at the 53rd ann mtg, SAA, Phoenix.

Benz, BF and Iltis, HH, (ms), Studies in archaeological maize. I: The "wild maize" from San Marcos Cave: Subm to Am Antiquity.

Creel, D and Long, A, 1986, Radiocarbon dating of corn: Am Antiquity, v 51, no. 4 p 826-837.

Damon, PE, Long, A and Wallick, EI, 1973a, On the magnitude of the 11-year radiocarbon cycle: Earth Planetary Sci Letters, v 20, p 300-306.

1973 b, Comments on "Radiocarbon: short-term variations" by MS Baxter and JG Farmer: Earth Planetary Sci Letters, v 20, p 311-314.

Donahue, DJ, Jull, AJT and Zabel, R, 1984, Results of radioisotope measurements at the NSFUniversity of Arizona Tandem Accelerator Mass Spectrometer Facility: Nuclear Instruments \& Methods, v B5, p 162-166.

Iltis, HH, 1983, From teosinte to maize: the catastrophic sexual transmutation: Science, v 222, p 886-894.

Johnson, F and MacNeish, RS, 1972, Chronometric dating, in Johnson, F, ed, The prehistory of the Tehuacan Valley, vol 4: Chronology and irrigation:Austin, Univ Texas Press.

Long, A, Ford, RI, Donahue, DJ, Jull, AJT, Linick, TW, Warneke, LE and Toolin, LI, (ms) 1986, Ages of first cultigens in southwestern US inferred from accelerator mass spectrometric analysis of ${ }^{14} \mathrm{C}$ on corn, beans and squash: Paper presented at the 51st ann mtg, SAA, New Orleans.

MacNeish, RS, 1981, Tehuacan's accomplishments, in Sabloff, J and Bridker, V, eds, Supp, Handbook of Middle American Indians, vol 1: Austin, Univ Texas Press.

1985, The archaeological record on the problem of the domestication of corn: Science, v 143, p 171-178.

Mangelsdorf, PC, 1974, Corn: Its origin, evolution and improvement: Cambridge, Massachusetts, Belknap Press of Harvard Univ Press.

Mangelsdorf, PC, MacNeish, RS and Galinat, WC, 1964, Domestication of corn: Science, $\mathrm{v} 143, \mathrm{p}$ 538-545.

1967, Prehistoric wild and cultivated maize, in Byers, D, ed, Prehistory of the Tehuacan Valley, vol 1: Austin, Univ Texas Press.

Pearson, GW and Stuiver, M, 1986, High-precision calibration of the radiocarbon time scale, 500-2500 BC, in Stuiver, M and Kra, RS, eds, Internatl ${ }^{14} \mathrm{C}$ conf, 12th, Proc: Radiocarbon, v 28, no. 2B, p 839-862.

Slota, PJ, Jr, Jull, AJT, Linick, TW and Toolin, LJ, 1987, Preparation of small samples for ${ }^{14} \mathrm{C}$ accelerator targets by catalytic reduction of CO: Radiocarbon, v 29, no. 2, p 303-306.

Stuiver, $M$ and Pearson, GW, 1986, High-precision calibration of the radiocarbon time scale, AD 1950-500 BC, in Stuiver, $\mathrm{M}$ and Kra, RS, eds, Internatl ${ }^{14} \mathrm{C}$ conf, 12 th, Proc: Radiocarbon, v 28, no. 2B, p 805-838.

Wills, WH, (ms) 1985, Early agriculture in the Mogollon Highlands of New Mexico: PhD dissert, Univ Michigan, Ann Arbor. 